Flint-Finds in Connection with Sand.

Author(s): Reginald A. Smith

Source: The Journal of the Royal Anthropological Institute of Great Britain and Ireland, Vol. 44

(Jul. - Dec., 1914), pp. 376-384

Published by: Royal Anthropological Institute of Great Britain and Ireland

Stable URL: http://www.jstor.org/stable/2843360

Accessed: 30-12-2015 08:33 UTC

Your use of the JSTOR archive indicates your acceptance of the Terms \& Conditions of Use, available at http://www.jstor.org/page/ info/about/policies/terms.jsp

JSTOR is a not-for-profit service that helps scholars, researchers, and students discover, use, and build upon a wide range of content in a trusted digital archive. We use information technology and tools to increase productivity and facilitate new forms of scholarship. For more information about JSTOR, please contact support@jstor.org. 


\title{
FLINT-FINDS IN CONNECTION WITH SAND.
}

\author{
By Reginald A. Smith, F.S.A.
}

A FEW recent discoveries, that perhaps have nothing in common but their connection with sand, seem to be worth collecting, as their significance may be under-estimated by those who see one or other of them in various periodicals, some of which are not easily accessible. There being no other necessary connection between these flint-finds, it would be easy to put down to a series of accidents their presence in sand; but apart from sand-hills in certain localities, it seems that the natural agencies that were responsible. for the sand (and other deposits possibly allied to it) are no longer in operation, and the problem is to determine when their work was accomplished and, by implication, the date or dates of the included human relics.

In June 1913 a generous grant from the Percy Sladen Memorial Fund enabled me to conduct excavations on a site that has become famous through Mr. Reid Moir's discoveries below the Crag, but has also added to his collection a number of peculiar flints from another horizon, which are now deposited in Ipswich Museum. With the kind co-operation of himself and Mr. Dewey of H.M. Geological Survey, I made a systematic examination of the site from which many worked flints had been already recovered, a black band being exposed some four feet from the surface, near the path on the north side of Messrs. Bolton and Laughlin's brickyard just outside Ipswich (Fig. 1). An account of the supposed "floor" at that spot has been published by Mr. Reid Moir in the Ipswich Field Club Journal, 1913, from which some of the following details are quoted. The surface of this part of the brickyard has been somewhat disturbed, and the path just above it probably altered the level, but the lower part was undisturbed. The section bared was as follows:-

Turf and soil (probably moved).

Sand, 3 feet.

Carbonaceous sand, wet, with numerous "pot-boilers," 1 foot 7 inches.

Dry yellow sand, 7 feet from surface and (close by) 5 feet deep, over London Clay.

The black band stopped on the east side of our trench, but extended for at least 25 feet, and may be regarded as an ancient hearth, on which flints had been heated and then plunged into water. Practically nothing but these crackled flints 
came to light on that occasion, and pits were dug at 13 other spots, the sections being fairly uniform as follows:-

Turf and minimum of soil.

Pure sand, about 3 feet thick.

Hearth or "floor" from 6 to 12 inches thick, with burnt flints, flakes, etc., or horizon marked only by coffee-coloured stain.

Yellow sandy loam, 2-4 feet thick.

London Clay, at about 7 feet from surface.

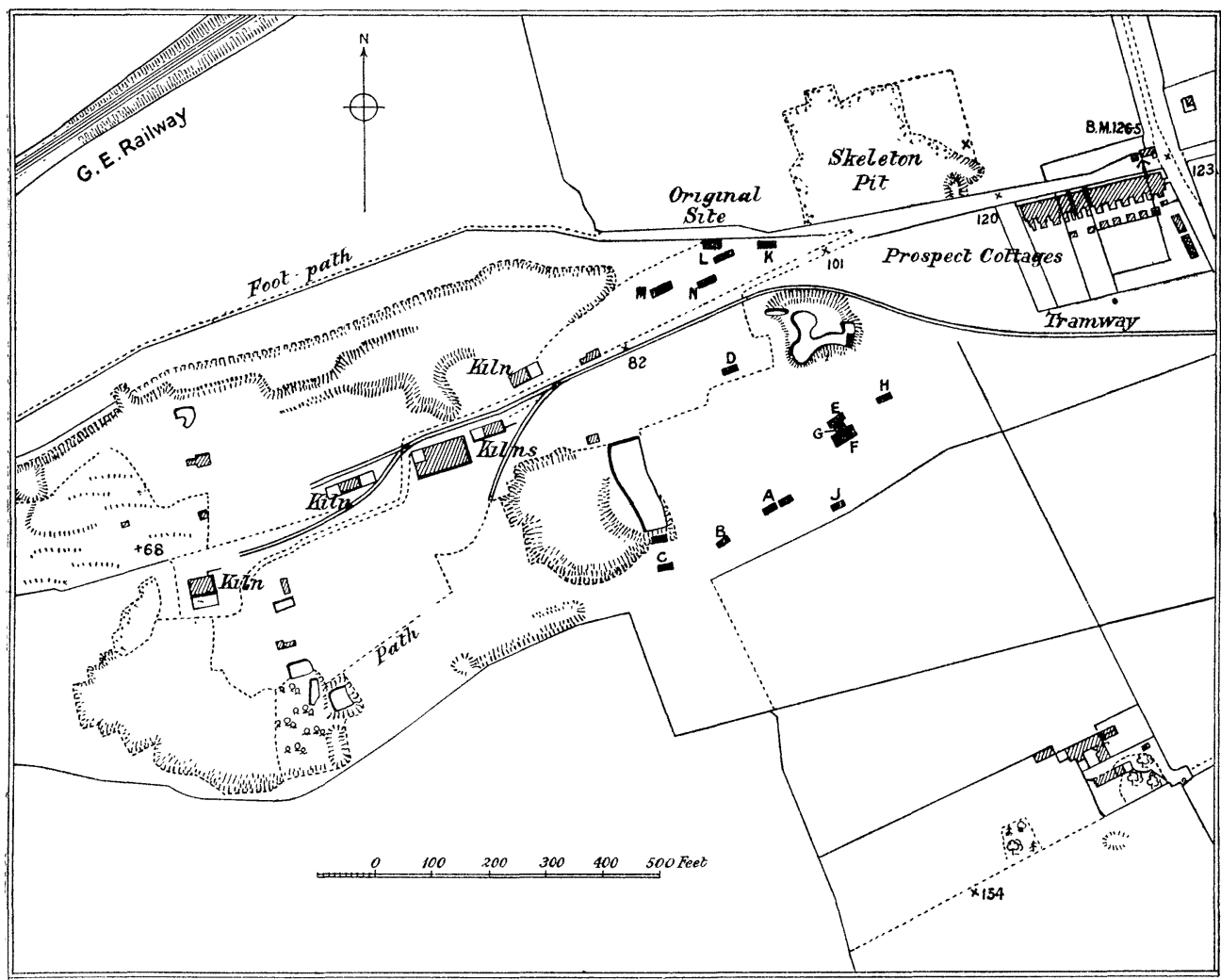

Fig. 1.-PLAN of MeSSRS. Bolton AND LAUGHLIN'S PIT NORTH OF IPSWICH, SHOWING TRIAL-PITS $(\mathrm{A}-\mathrm{N})$ DUG IN 1913.

By joining pits $\mathrm{E}, \mathrm{F}$ and $\mathrm{G}$ a large hearth was discovered, the bottom sloping with the hill (about 1 in 4 ) and extending over about, 200 square feet. It was oval in outline, 20 feet north and south (on the slope) and 11 feet wide through the middle. It was 1 foot thick in the centre, and $1 \frac{1}{2}-2 \frac{1}{2}$ feet below the surface, being covered with grey sand and resting on white sand. Pit $\mathrm{J}$ was dug close below the hedge which marks a feature, the site being approximately level with the original hearth on the opposite side of the valley; but the pit showed no signs of a "floor," only $2 \frac{1}{2}$ feet of grey sand above caked yellow sand entirely free of stones.

In the centre of the valley (pit D) there was no trace of a "floor," but merely 
pebbles, quartz and other stones at 4 feet from the surface below pure sand; but a little further east, up the valley, a section was cut on the edge of the pond, and the floor-level found at about 2 feet. Above it was dark sand; and below, about 4 feet of loamy sand resting on London Clay. Mr. Dewey suggests that the "floor" once extended across the valley but has been washed away by a water-course at some remote date, there being no stream at the present day.

Though the flints and other remains found during these excavations were of little evidential value and indeed insignificant, it was a satisfaction to establish an occupation level practically all over this part of the brickyard, which had been buried at some date under 3 feet of pure, almost impalpable sand. If the deposit. is merely hill-wash, it is curious that so few pebbles or other stones were included in it either above or below the floor. In such a case any evidence from the flints and other finds would be welcome, and the series collected by Mr. Reid Moir on the most prolific site do indeed present a homogeneous appearance. They are nearly all brownish-black, quite fresh and sharp, uniformly small and stumpy with parallel flaking on the worked parts; and permission has been freely granted for the reproduction of several specimens (Figs. 2-7). The rarity of paitina is not a
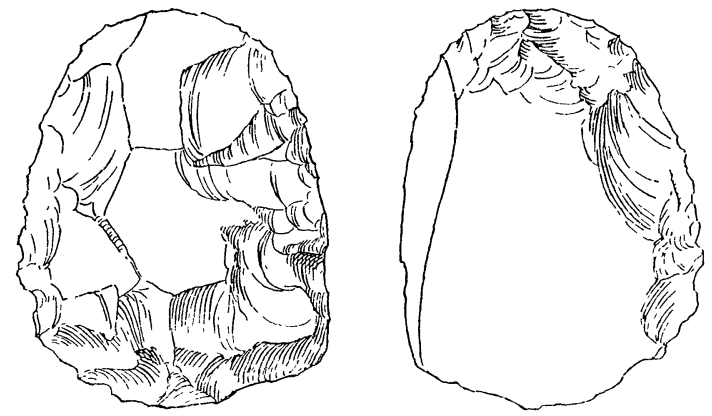

FIG. 2.-THIN IMPLEMENT, FRONT AND BACK VIEWS : IPSWICH $\left(\frac{2}{3}\right)$.
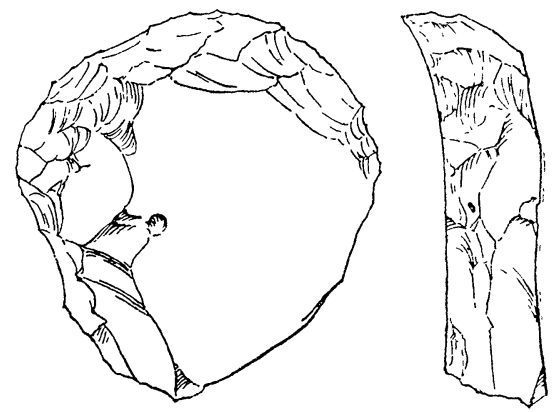

FIG. 3.--STEEP ROUND-SCRAPER, FRONT AND SIDE VIEWS : IPSWICH $\left(\frac{2}{3}\right)$.

serious difficulty, as the oldest French cave series, from Le Moustier cavern, is normally unchanged; and the only known dated industry that is at all similar is the Aurignac series of the palæolithic cave-period of France. The resemblance may be deceptive and such peculiar forms may conceivably belong to another or to several stages of the Stone Age ; but at present we must either regard them as undatable or connect them with the Aurignac culture which is known to be represented in this country (as at Paviland Cave and Wookey Hole). As there are no caves near Ipswich, prehistoric man must either have avoided the neighbourhood altogether or left his remains on or near the surface. Geological research may determine whether the layer of sand is the gradual accumulation of centuries or a deposit assignable to one period and to particular circumstances.

Another investigation of considerably greater importance, but perhaps of less interest in England, has been conducted by an eminent geologist, who has been criticised, as was natural, but maintains his ground and persists in what the 
orthodox archæologist is only too ready to denounce as heresy. I do not pretend to any knowledge of the geology of Schleswig-Holstein or any other region, and it
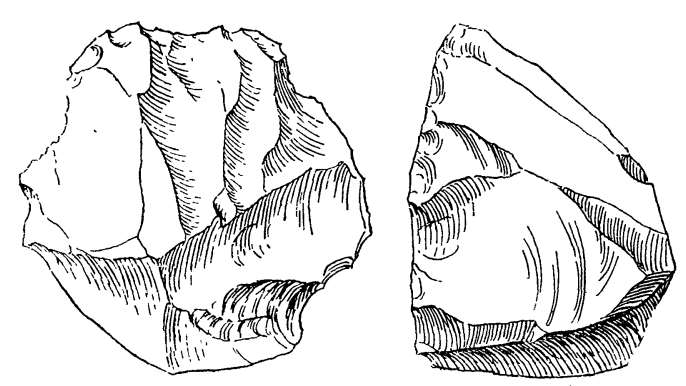

Fig. 4.-CONE WITH SQUARED NOSE, TOP AND SIDE VIEWS : IPSWICH $\left(\frac{2}{3}\right)$.
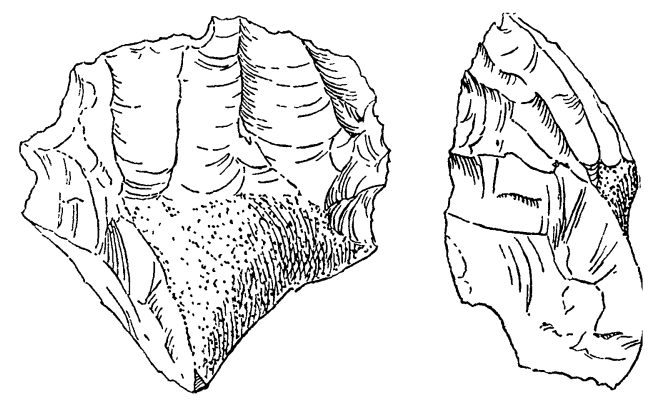

FIG. 5. - SUB-CONICAL STEEP-NOSED SCRAPER, TOP AND SIDE VIEWS : IPSWICH $\left(\frac{2}{3}\right)$.

is fortunate that the alleged facts not only speak for themselves but have attracted the attention of other competent observers, so that a settlement of the question cannot be long delayed.

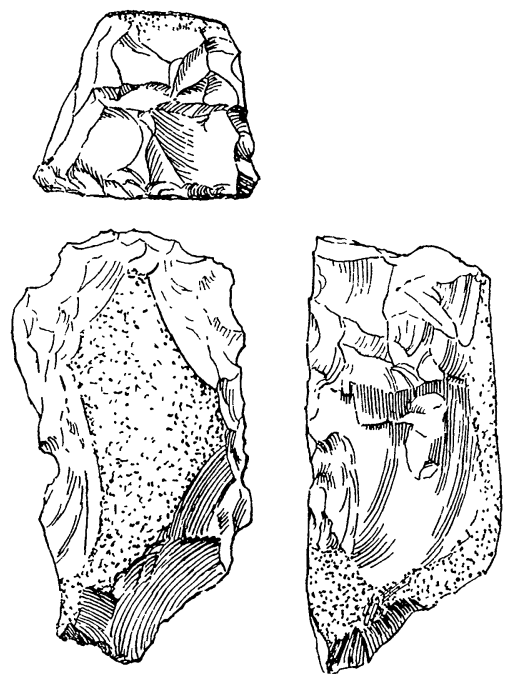

FIG. 6. - PLANE WITH STEEP END AND SIDES; END, TOP AND SIDE VIEWS : IPSWICH $\left(\frac{2}{3}\right)$.

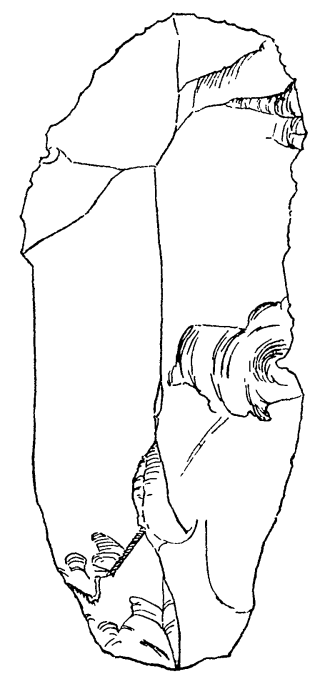

FIG. 7.-RIDGED BLADE WITH SOME FLUTING : IPSWICH $\left(\frac{2}{3}\right)$.

In May, 1911, Professor Dr. C. Gagel reported to the German Geological Society $^{1}$ on what he called, with some hesitation, early neolithic finds in the later glacial deposits of West Holstein; and suggested some modification of prevalent views as to the postglacial date of certain so-called neolithic implements. In a railway gravel pit at St. Michaelisdonn, west of the southern end of the Kiel Canal and about six miles north of the mouth of the Elbe, worked flints have been found in some quantity in the Geschiebedecksand (glacial sand over boulder clay) or

1 Zeitschrift, B. Monatsberichte, No. 5, 1911, p. 249 ; and ibid., No. 12, p. 620. 
upper Drift deposit of that region. The section was as follows, in descending order :-

1. Fine-grained, black Heidesand with Dreikanters (stones worn into facets by blown sand) at the base $\quad \ldots \quad \ldots \quad \quad \ldots \quad 1-1 \frac{1}{2}$ feet.

2. Unstratified brownish yellow Geschiebedecksand, slightly loamy in places, smaller pebbles in upper part and larger pebbles below $\quad \ldots \quad \ldots \quad \ldots \quad \ldots \quad \ldots \quad \ldots \quad \ldots$ $1 \frac{1}{2}-2 \frac{1}{2}$ feet.

3. Irregularly stratified, light-coloured sand, without stones, but with bank of brown sandy Geschiebelehm (boulderclay) $\ldots \quad \ldots \quad \ldots \quad \ldots \quad \ldots \quad, \ldots \quad \ldots \quad \ldots \quad \ldots-6 \frac{1}{2}$ feet.

4. Morainic bank (oberer Geschiebemergel ?)

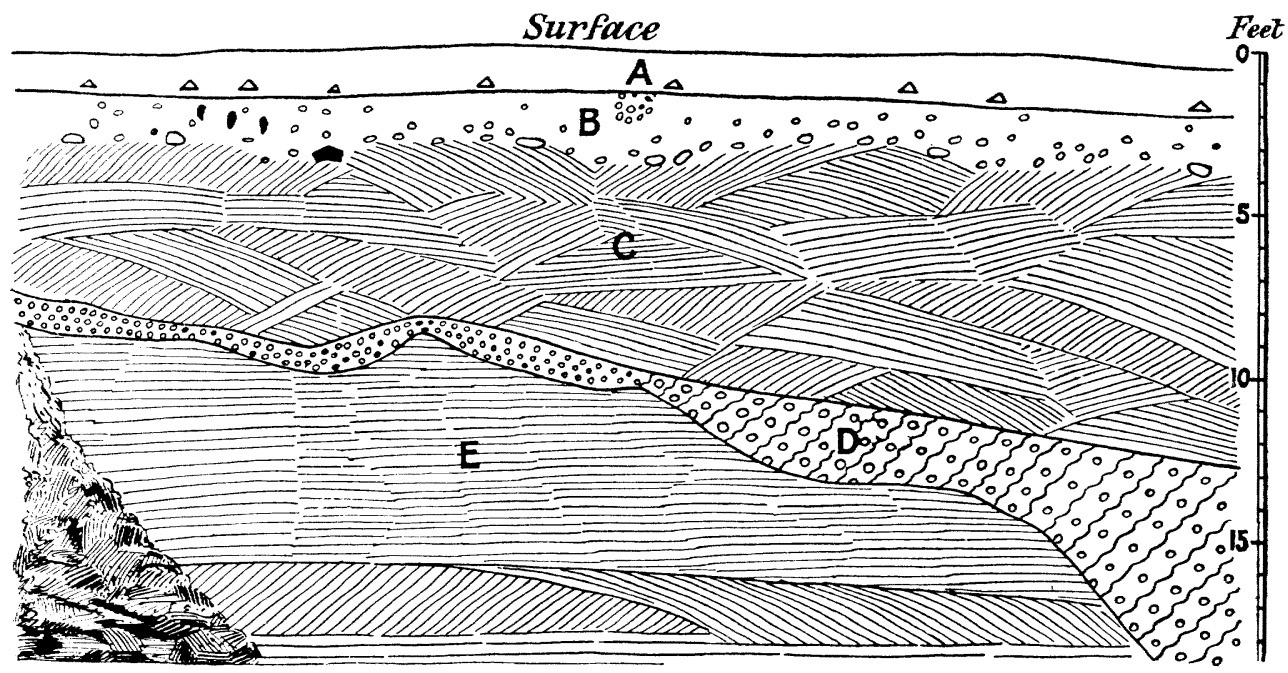

Fig. 8.-First SECTION AT ST. MICHAELISDONN (AFTER GAGEL, APRIL, 1911).

A.-Black heath-sand with Dreikanters.

B.-Glacial sand with pebbles and worked flints in upper part.

C.-Current-bedded sand.

D.-Boulder clay.

E.-Moraine bank, with fallen material on left in which some flints were found.

Worked flints were found about $1 \frac{1}{2}$ feet below the junction of beds 1 and 2 , including some with white patina; and the same association occurred at the base of the Geschiebedecksand (bed 2), above the false-bedded sand. The flakes and implements figured show no resemblance to Drift forms, and the best specimen is like a short Thames pick, the type usually associated with the transverse axe (tranchet, Skivespalter) of the Danish middens and earlier sites, such as Maglemose. The flints were nearly all quite sharp and had evidently not been rolled to any appreciable extent, the conclusion being that they were chipped on the spot by men who sought their raw material among the flints washed out of a moraine on the 
melting of the glacier. It was clear that the flints got into their sand-bed before the black upper sand was deposited on a band of wind-polished stones. Various objections to this interpretation of the section were discussed by Professor Gagel, who suggested on a subsequent occasion ${ }^{1}$ the following sequence of events :-

1. Ground-moraine of the principal glaciation (lower zone).

2. Fresh, unweathered intermediate deposits with undoubted palæolithic implements.

3. Undoubted ground-moraine of the principal glaciation (upper zone).

4. Interglacial weathered zone in old Drift gravel also with palæolithic implements.

5. Interglacial peat, with plants typical of the last interglacial period but now extinct in Europe; also oak, ash and other trees, with palæolithic implements and signs of a warm climate.

6. Undoubted deposits of the last glaciation (sandy ground-moraine with large boulders).

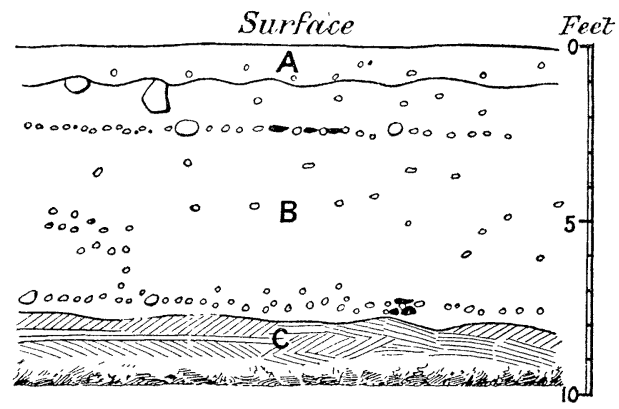

Fig. 9.-SECond SeCtion AT St. Michaelisdonn (AFTER GAGEL, SEPtember, 1911).

A.-Black heath-sand.

B.-Glacial sand, with two pebble layers in which worked flints were found, and boulder (perhaps not in situ) at the top.

C.-Current-bedded sand.

The late Professor Koken noticed this find in Die diluviale Vorzeit Deutschlands, a sumptuous work written in association with R.R. Schmidt and Schliz. Translated, the passage reads (p. 215):- "Still more surprising than the occurrence of eoliths in very old Drift beds is the announcement of worked flints regarded as neolithic in glacial sand (Geschiebesand), where, to judge from south German finds, one would expect Le Moustier types. Gagel assigned his series from this deposit in West Holstein to the neolithic period. One knife, figured in his paper, suggests the neolithic blades found in the sand-dunes near Brunswick. The description does not preclude the possibility that they came, not from the glacial sand, but from the alluvial heath-sand, for they were picked up off fallen material, and only a few (not figured) came direct from the undisturbed strata. Gagel recently supplemented

1 Zeitschrift fiir Ethnologie, 1913, 155. 
his communication and insisted that the original position of the flints in the glacial sand and their attribution to the climax of the last northern glaciation were beyond all doubt. The specimen figured is, on the other hand, neolithic. $\mathrm{He}$ contends that the layer of worked flints belongs to the glacial sand, and it is open to question whether the sand was due to the last or the last but one glaciation. If Gagel were right in supposing that traces of mesolithic man have been found in situ in an undoubted glacial deposit, we should be confronted with a very difficult problem."

To return to England, reference may next be made to a brief report presented to the East Anglian Prehistoric Society, from which I freely quote.

In the spring of 1913 an interesting discovery was made about a mile north of Icklingham, in the north-west corner of Suffolk. The site is about $160 \mathrm{ft}$. O.D., on the edge of a sandy plateau which forms the continuation of the Boulder-clay area and is the last high ground towards the Fens. The ground was being trenched two spades deep at the head of a short dry valley sloping southward to the Lark, and in places the broken surface of the chalk was found below the sand at about 18 inches from the surface, though elsewhere the sand was 4 feet or more in thickness. Dr. Allen Sturge subsequently made investigations, and had special trialholes sunk to the chalk in view of the discovery by the workmen of a working-floor of the Stone Age, with flint flakes and implements to the number of two hundred, together with charcoal from hearths. According to his report in the Proceedings of the Prehistoric Society of East Anglia, vol. i, part iii, p. 292, the majority were patinated on one face only, and the rest were patinated unequally on the two faces; all were without scratches, lustre, or iron-moulding, in marked contrast to the multitude of surface-flints collected on the sloping ground immediately south of the "floor." The floor-pieces have a dead white patina, and are expressly compared with the series from Grime's Graves, those prehistoric flint-mines being about 11 miles north of the present site, in a very similar position with regard to the Boulder-clay plateau, the Fens and the river. Dr. Sturge remarks on the strange fact that three of the implements might, so far as their shape goes, have come from palæolithic gravels, and gives photographs of both faces in each case. "One is a large ovate-lanceolate implement 9 inches long, recalling the limande of the St. Acheul deposits; another is a pointed implement with thick butt, $5 \frac{1}{2}$ inches long, showing a close resemblance to well-known gravel types; and the third is a pointed ovate, $3 \frac{1}{2}$ inches long, of a pattern practically identical with those from the Warren Hill gravels. With these three lay a chipped celt with parallel sides, of the type so familiar as coming from Cissbury." Flakes and implements evidently belonging to the same culture have been collected not only on the sites mentioned, but also elsewhere in East Anglia ; and in Dr. Sturge's opinion resemble Drift and neolithic forms, rather than those of the Cave period. They are, however, all of the same date and origin, and include no examples of polish. Another link between the Icklingham floor, Grime's Graves, and Cissbury is the occurrence at all three places of large flint blocks weighing up to 3 or $4 \mathrm{lbs}$., more or less circular and 
roughly chipped; and with all deference to Dr. Sturge, I cannot help regarding this recent discovery as a strong argument for the palæolithic date of Cissbury and Grime's Graves, as already suggested in Archoeologia, lxiii, 108 (May, 1912). Mention is made in that paper of the geological aspect of Grime's Graves, inasmuch as Canon Greenwell had to penetrate 13 feet of dark yellow sand before he came to the solid chalk in which the prehistoric shaft had been sunk. ${ }^{1}$ Icklingham produces the same kind of worked flints under sand, which must have been deposited after the flints were chipped and (according to Dr. Sturge) before the surface-flints on the slope were manufactured, the latter being heavily scratched in thousands of cases. The pall of sand is referred by him to a desert period between the two flint periods or groups of periods.

Two chipped celts of particularly symmetrical form may be mentioned as having been found under exceptional conditions. One is in Mr. W. M. Newton's collection at Dartford, and was found on the north side of Dartford Heath under 3 feet of sand. The patina is grey, and the length 6-7 inches. The other was found at the entrance of the N.W. Cave, Gop, Cheshire, under 2 feet of cave-earth, ${ }^{2}$ and is figured in Mr. Glenn's account of recent excavations there. It might be objected that cave-earth is not sand, and the deposit had slipped or silted over a neolithic implement; but when several more finds of this kind have been put on record, the question will arise whether these human relics may not after all be in situ, as silent witnesses of geological phenomena in the early history of the race.

Having hitherto kept almost exclusively to sand-deposits, I may be allowed to allude to a cognate subject, the Rhine loess, usually considered of aeolian origin, and the human industries found in its various strata. The subject is highly controversial, ${ }^{3}$ but most investigators would agree that the beds at Achenheim, for example, were laid down over a long period, beginning with the late Drift (St. Acheul period) and ending with Aurignac, about the middle of the Cave period. It rests mainly with geologists to determine whether there was any corresponding deposit in this country; and in view of the close agreement between the Thames and Somme deposits (the latter having two strata called loess by Professor Commont), there is every prospect of linking up our pleistocene deposits with the Continent. In fact Mr. Clement Reid has for some time thought that the loess was represented by certain deposits on the Downs, but sufficient archæological evidence has not been accumulated to prove his contention.

Though the Rhine loess is still under discussion and is indeed a burning question, certain facts connected with it are established, and agree with the evidence at present available on the Danube. At Hundsteig, Krems, 40 miles above Vienna,

1 This statement must be modified in view of recent excavations at Grime's Graves. The sand measured by the Canon seems to have included part of the filling.

${ }^{2}$ A few words on cave-earth, loess and other deposits possibly related may be found in Archocologia, lxiii, 143.

${ }^{3}$ References in R. R. Schmidt's Diluviale Vorzeit Deutschlands, pp. 64, 170, 195. The Austrian loess is said to date almost exclusively from Aurignac times. 
a rich Aurignac industry was collected in loess 40 feet thick, and the account by Strobl and Obermaier ${ }^{1}$ includes nine plates of worked flints that give an excellent idea of the Aurignac facies.

The principal sites on the Rhine besides Achenheim in Alsace, west of Strasburg (R. R. Schmidt, Die diluviale Vorzeit Deutschlands, 63, 195) are Munzingen (Freiburg-im-Breisgau, west of the Black Forest; Schmidt, pp. 67 and 200) and Metternich (on the Mosel near Coblenz; Schmidt, p. 86). Divergent views on the relation of these deposits to the principal glaciations have been published by F. Wiegers (Prähistorische Zeitschrift, i (1909), 16) and Dr. Bayer (Jahrbuch für Altertumskunde, iii, 149; iv, 154, and Zeitschrift für Ethnologie, 1912, pp. 1, 180; scheme reproduced in Archoolgia, lxiii, 143). Whatever the ultimate decision on that point, it is clear that the loess was laid down about the middle of the palæolithic Cave period; and though we can point to no such gigantic deposits in England, it is most unlikely that the culture is not fully represented at least in south-east England. Once more Aurignac man is shown to have lived in the open as well as in caves, a fact that cannot be emphasized too strongly at the present juncture.

Further afield-important finds in sand, practically identical with European palæolithic forms, have been recorded in Tunis, Egypt and Somaliland, but a more obvious explanation of the sand deposit is available in these cases. In England collectors have been busy on sandy stretches in Surrey, such as Blackdown (near Haslemere), ${ }^{2}$ and Blackheath (south of Chilworth), but the flints have not been fully described and are difficult to date. ${ }^{3}$ There is a family likeness observable, and some significant steep fluting on conical lumps, but no corroborative details as in the caves, where the explorer's task is comparatively easy. On the sites just mentioned there is an outcrop of sand, and their interest lies solely in the flints discovered, but cases have been quoted where the deposit was later than the human occupation. Whether the sand is an important element in the matter of dating, careful geological examination can alone decide; its presence on some sites is at any rate not readily intelligible to the archæologist.

In conclusion, I can only express the hope that collectors will assist in solving such problems as I have outlined above by supplying the geologist with accurate archæological evidence as a substitute for the natural fossils that are in most cases altogether wanting. Finds on the surface may be and often are extremely interesting, but for scientific purposes cannot compare with flints sometimes lying a few inches below it.

1 Jahrbuch für Altertumskunde, iii (1909), 129.

2 Mr. E. W. Swanton, who is in charge of the find at Haslemere Museum, informs me that they occur below 4 in. of peat on the Hythe beds at 900 feet O.D.

3 Since this paper was read, a fine series of Aurignac types has been collected from a "floor" under sand in Surrey, a close parallel being thus provided for Mr. Reid Moir's discovery of Cave types at Ipswich. 